\title{
中新世全球重要事件及其意义: 数据挖掘的启示
}

\author{
刘欣雨 ${ }^{1}$, 张旗 ${ }^{2 *}$, 张成立 ${ }^{1 *}$, 袁方林 ${ }^{1}$, 焦守涛 ${ }^{3}$ \\ 1. 西北大学地质学系, 大陆动力学国家重点实验室, 西安 710069; \\ 2. 中国科学院地质与地球物理研究所, 北京 100029 ; \\ 3. 中山大学地球科学与地质工程学院, 广州 510275 \\ *联系人, E-mail: zq1937@126.com; clzhang@nwu.edu.cn
}

2016-09-10 收稿, 2016-11-10 修回, 2016-11-11 接受, 2017-03-02 网络版发表

大陆动力学国家重点实验室自主研究课题和创新团队发展计划(IRT1281)资助

\begin{abstract}
摘要 GEOROC(Geochemistry of Rocks of the Ocean-sand Continents)是大陆和海洋岩石的地球化学数据库, 利用 该数据库着重研究了全球新生代汇聚边缘安山岩和玄武岩、裂谷安山岩和玄武岩、洋岛安山岩和玄武岩、埃达克岩 等岩浆岩的时空分布特征。结果表明, 全球岩浆活动或在中新世开始活跃, 或在中新世达到巅峰状态. 形成于不同 构造环境的岩浆岩具有不同的地质意义: 汇聚边缘岩浆岩发育, 暗示板块俯冲作用强烈; 裂谷岩浆岩大量喷发, 表 示发育与板块扩张有关的岩浆活动; 洋岛岩浆岩迅速增加, 指示下地幔异常活跃; 埃达克岩广泛分布, 表明许多地 方受到构造挤压作用，导致地壳加厚。由此推测，全球在中新世可能发生了一次重大的、全球性的岩浆事件. 除此之 外, 全球中新世还发生了一系列重要事件, 如青藏高原的隆升及黄土高原的形成、安第斯的抬升、地中海的千涸、 全球荒漠化以及西太平洋边缘海盆的发育等. 岩浆活动与构造运动通常是相伴而生的, 二者间的相互作用改变了古 地理、古气候、古环境. 中新世剧烈的岩浆活动与构造活动相互作用可能导致地壳加厚或隆起, 形成的山脉、高原 改变了原有的地形地貌, 影响了大气环流, 从而改变了地表环境. 因此, 研究中新世岩浆-构造-气候-环境之间的相 互关系, 可能是目前和未来一个需要地学工作者长期探索的课题. 此外, 随着大数据技术的不断发展, 科学研究也 逐渐步入大数据时代. 从全体数据出发, 探讨数据之间的关联关系, 或许为今后的科研工作提供了一个新的思路.
\end{abstract}

关键词中新世, 事件, 火山岩浆活动, 数据挖掘

目前全球已经积累了海量的岩石、矿物地球化学 和同位素年龄数据, 并建立了多个相关数据库. GEOROC (Geochemistry of Rocks of the Ocean-sand Continents) 是大陆和海洋岩石的地球化学数据库, 由 德国Max Planck化学研究所的Sarbas研究小组负责建 设和维护. 数据库定期更新相关数据, 并支持多种查 询方式, 免费供科研工作者网上下载 ${ }^{[1]}$. 本文从该数 据库中篮选出新生代安山岩和玄武岩(包括洋岛、裂 谷、汇聚边缘三种环境), 以及埃达克岩和中酸性岩 浆岩的样品信息, 对不同时代的样品进行数量统计.
需要说明的是, 本文的统计为数据库中的数据量, 而 非岩浆岩规模、喷发强度、喷发体积等资料(这些资 料目前还无法在全球范围内予以查明). 这种方法尽 管有一定的局限性, 但全体数据是随机取样的结果, 因此样品的数据量在一定意义上可大致代表岩浆岩 的分布及强度情况.

\section{1 中新世全球岩浆活动记录}

对全球新生代安山岩、玄武岩及中酸性岩浆岩的 年代数据进行挖掘统计表明, 新生代洋岛安山岩 
(图1(a)) 以中新世时期的数据量最多, 暗示洋岛安山 岩可能主要形成于中新世; 新生代洋岛玄武岩(图 1 (b))虽然在更新世分布最多, 但早期分布很少, 直到 中新世才开始明显增多. 新生代裂谷安山岩(图 1(c)) 和玄武岩(图1(d))均在中新世最为发育. 新生代汇聚 边缘安山岩(图1(e))从中新世开始大量产出; 新生代 汇聚边缘玄武岩(图1(f))主要喷发于中新世和更新世. 新生代埃达克岩(图1(g)) 和新生代中酸性岩浆岩(图
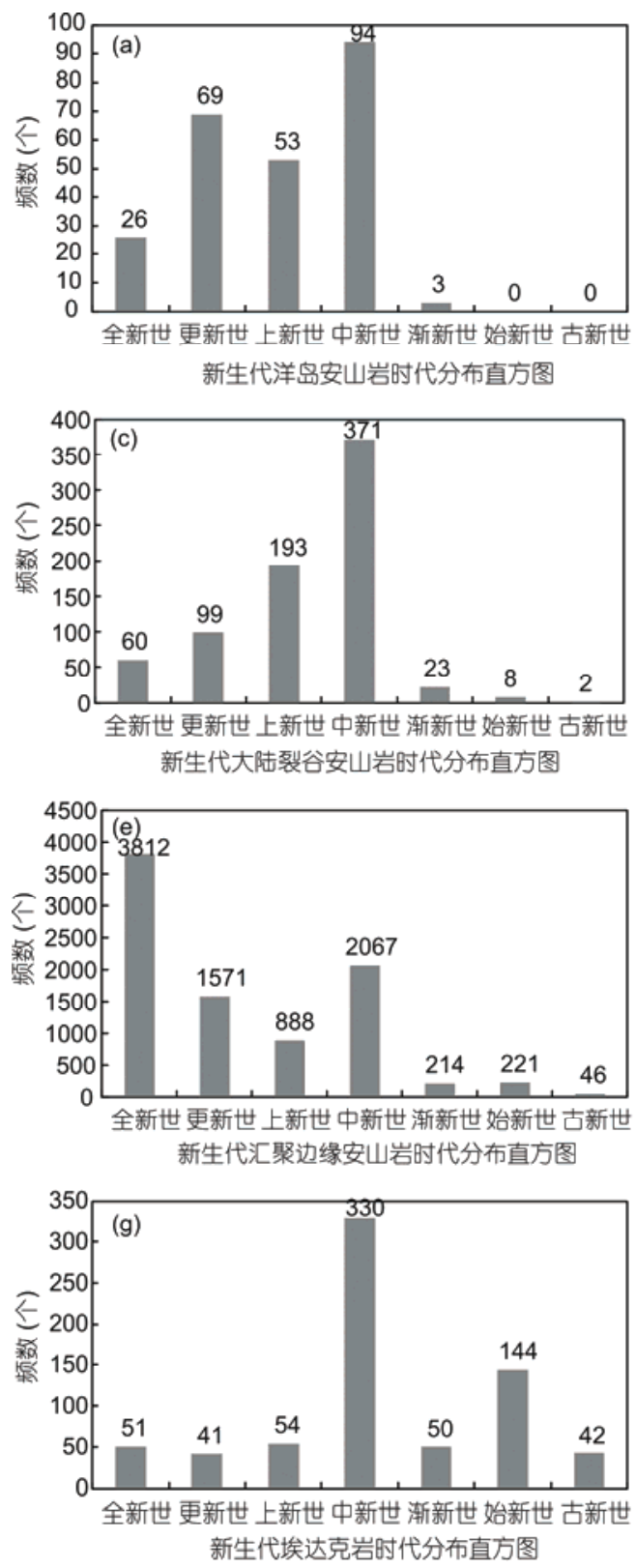

1(h))也表现出了中新世明显增多的特征.

汇聚边缘岩浆岩发育, 暗示板块俯冲加速; 裂谷 安山岩和玄武岩大量喷发, 表明与板块扩张有关的 岩浆活动发育; 洋岛安山岩和玄武岩急剧增加, 指示 下地幔异常活跃，导致来自下地幔的物质增加; 中酸 性岩浆岩的出现代表下地壳底部温度高, 软流圈上 涌强烈，地壳改造强烈；埃达克岩多表明构造挤压强 烈，导致许多地方地壳加厚. 由此推测, 全球在中新
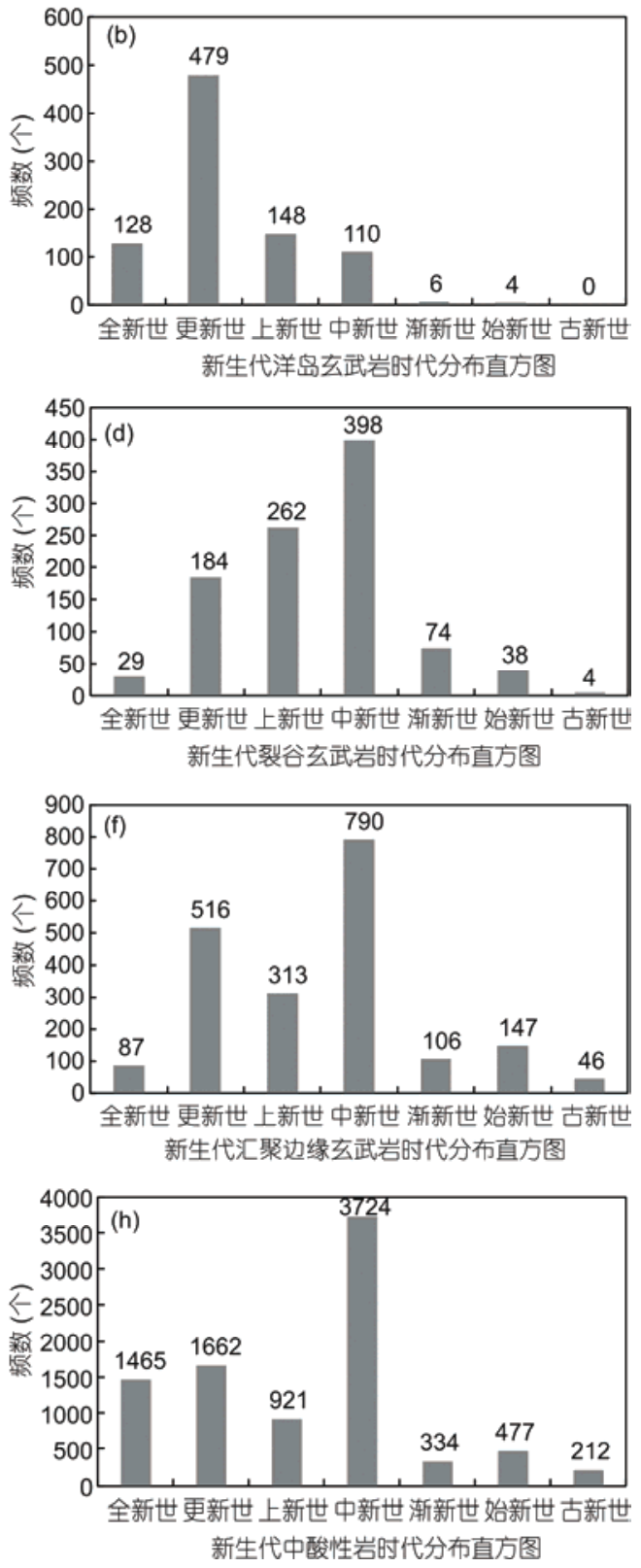

图 1 全球新生代岩浆岩时代分布直方图

Figure 1 Age distribution histogram of global igneous event during Cenozoic 
世可能发生了一次重大的、全球性的岩浆事件.

\section{2 中新世全球事件的记录}

事实上, 除了剧烈的岩浆活动以外, 全球在中新 世时期还发生了一系列重大地质事件. 青藏高原的 崛起、安第斯的抬升、地中海的干涸、西太平洋边缘 海盆的形成、大洋深水沉积物的增加以及黄土高原的 形成等都发生于渐新世-中新世期间或在中新世时期 达到鼎盛. 伴随着地形地貌的改变, 全球的气候环 境、生物分布也渐渐发生变化, 非洲撒哈拉大沙漠、 中亚塔克拉玛干大沙漠的形成以及人科动物在非洲 的出现也都始于中新世.

\section{1 青藏高原的崛起及其对气候环境的影响}

印度板块和欧亚板块在55 Ma左右发生碰撞 ${ }^{[2,3]}$, 然而与碰撞同期形成的林子宗组火山岩代表正常厚 度的地壳 ${ }^{[4]}$, 可知碰撞作用并未导致青藏高原抬升. 青藏高原的抬升始于 $40 \mathrm{Ma}$ 左右 ${ }^{[5]}$, 以出现在芫塘-金 沙江-红河一带的埃达克岩以及斑岩铜矿作为标志, 代表一个地壳加厚形成的山脉. 在渐新世晚期和中 新世早期, 以喜马拉雅地区的埃达克岩和喜马拉雅 型花岗岩、冈底斯埃达克岩、可可西里埃达克岩作为 标志, 指示青藏高原在该时期开始大范围抬升, 并在 中-晚中新世时期全面抬升 ${ }^{[4,6]}$.

中新世中期(18 16 Ma)贝加尔湖的张开, 汉诺坝 玄武岩的喷发, 扬子板块向东南逃逸导致的强烈走 滑, 南海的张开, 可能均与印度-欧亚板块的碰撞以 及青藏高原的抬升有关 ${ }^{[5,7 ~ 12]}$. 位于尼泊尔和印度边 界的主中央断层是25 22 Ma开始活动的, 来自主中 央冲断层的力可以传递到几千公里外的贝加尔湖地 $区^{[5,6,9,11,12]}$. 青藏高原在这个时期的抬升可能与主中 央冲断层的活动密切相关. 此外, 北至贝加尔、西到 兴都库什山、东到大兴安岭-太行山-雪峰山、南抵印 度-尼泊尔边界及中南半岛北部的中国-蒙古高原的 形成, 可能均与主中央冲断层的活动有关, 其构造加 厚作用波及大半个中国及周边邻国(图2(a)).

有关青藏高原的崛起对气候环境的影响, 国内 外学者做了很多研究, 迄今已取得巨大的成果. 例 如, 张仲石等人 ${ }^{[13]}$ 认为, 中国的环境在新生代期间 经历了从近于东西向的带状格局向与现今相似的非 带状格局的转变, 代表了东亚地区重大的环境变化, 而渐新世/中新世之交和中新世可能是这一环境变化
最为关键的时期. 研究显示, 以内陆干旱为基本特征 的非带状环境格局至少出现于中新世早期, 与中国 北方风尘堆积出现的时代具有一致性 ${ }^{[13 ~ 16]}$. 研究表 明，高原东北部在25 22 $\mathrm{Ma}$ 发生了显著的构造抬升 (图2(b)), 与亚洲内陆荒漠和东亚季风系统起源的时 间基本一致，暗示了季风起源与青藏高原北部隆升 的密切关系 ${ }^{[17]}$.

据安芷生等人 ${ }^{[18]}$ 研究, 中新世早期(24 22 Ma), 控制中国大陆环境的气候系统由行星风系为主导向 季风风系转变, 内陆干旱区和东亚季风区开始形成 分异, 黄土高原开始出现粉尘堆积, 夏季风发育东部 湿润区向北扩张, 南海扩张, 喜马拉雅和青藏高原中 南部隆升生长. 中新世中期(16 14 Ma), 西北干旱区 进一步扩大, 季风加强, 记录了青藏高原的又一次重 要生长事件. 10 7 Ma, 青藏高原又开始一次重要的 生长事件 ${ }^{[6,19]}$, 黄土高原风成红黏土堆积广泛发育, 内陆干旱化加剧，中国季风-干旱环境系统的格局基 本形成, 印度洋夏季风增强。上新世早期(3.6 2.6 $\mathrm{Ma})$, 青藏高原向北和东北生长, 高原的生长和大冰 期的来临导致了中国现代季风-干旱环境格局的形 成, 第四纪黄土-古土壤序列开始堆积. 上述 3 个时期 可能对应了青藏高原抬升的 3 个阶段.

\section{2 安第斯高原的抬升}

在安第斯地区出露大量埃达克岩, 通常包含3种 成因类型: (1) 安第斯地区的地壳构造加厚; (2) 弧前 地壳的俯冲-侵蚀; (3) 年轻洋壳的俯冲 ${ }^{[20]}$. 因此, 埃 达克岩增加的时期可大致等同于安第斯地区的地壳 加厚阶段.

Kay等人 ${ }^{[20]}$ 统计了安第斯地区岩浆岩 $(<27 \mathrm{Ma})$ 的 $\mathrm{Yb}$ 和 $\mathrm{Sr} / \mathrm{Yb}$ 值, 按照 $~ 27 \sim 18, \sim 16 \sim 8, \sim 8 \sim 3$ 和 $<2 \mathrm{Ma}$ 共4个时段进行投图, 并以 $\mathrm{Yb}<2 \mathrm{ppm}(1 \mathrm{ppm}=1 \mu \mathrm{g} / \mathrm{g})$ 和 $\mathrm{Sr} / \mathrm{Yb}>400 \mathrm{ppm}$ 为标准划分出埃达克岩区域(图 3(a)). 由图中可明显看出, 安第斯地区的埃达克岩主 要发育于 $16 \mathrm{Ma}$ 后. 换言之, 安第斯地区的地壳加 厚作用可能盛行于中新世时期.

\section{3 西太平洋边缘沟-弧-盆的形成}

西太平洋大陆边缘集中了全球 $75 \%$ 以上的边缘 海盆, 在西太平洋地区逐渐形成了巨型的沟-弧-盆俯 冲系统 ${ }^{[21,22]}$. 西太平洋板块的俯冲消减形成了伊豆小笠原-马里亚纳弧前玻安岩, 15 10 Ma岩浆产生的 

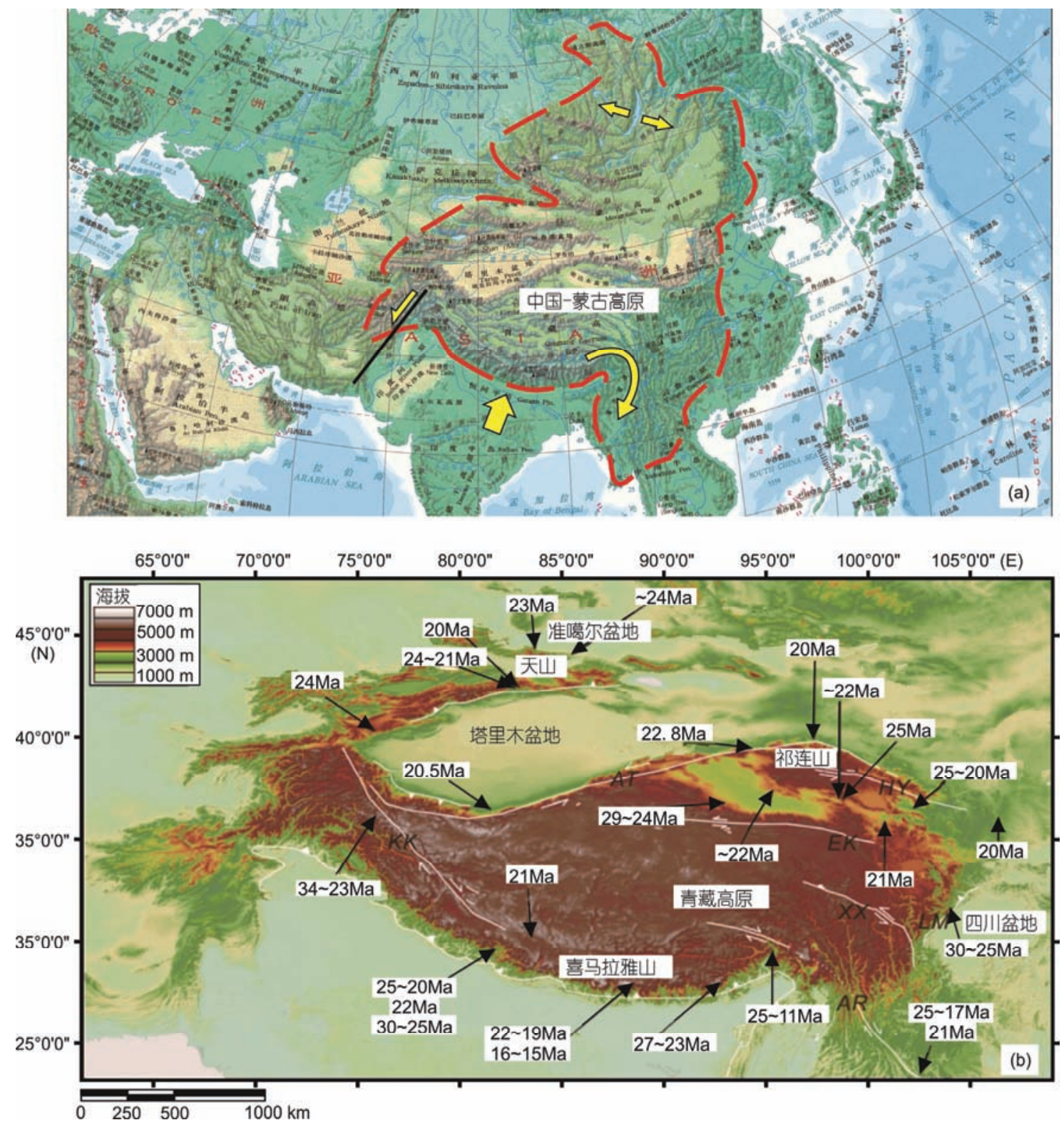

图 2 中国-蒙古高原范围示意图(a)和青藏高原 25 Ma构造抬升事件年龄分布图(b) ${ }^{[11,17]}$

Figure 2 Sketch map showing the China-Mongolia plateau range (a), and age distribution of tectonic uplifting events ( 25 Ma) in Tibetan Plateau (b) ${ }^{[11,17]}$

速率最快; 日本海在21 11 Ma打开, $15 \mathrm{Ma}$ 达到高峰; 劳海盆在14 5 Ma张开; 四国海盆在27 15 Ma张开; 冲绳海槽在中新世晚期(4 Ma)张开; 西菲律宾海盆在 60 35 Ma张开, 中新世中期开始向西俯冲(图4). 因 此, 西太平洋边缘海盆是古新世-始新世开始活跃的, 至中新世达到巅峰状态.

本文也利用数据库中的信息, 统计了安第斯地 区新生代埃达克岩的时代分布特征, 结果显示安第 斯埃达克岩开始增多的时期确实为中新世时期 (图 3(b)). 由此推断，安第斯高原很可能是从该时期开始 抬升隆起的.

\section{4 地中海干涸事件}

晚中新世末期(8 5 Ma)全球气候处于干旱状 态 $^{[24]}$, 此时, 西班牙贝特斯海峡和摩洛哥海峡先后 关闭 $(\sim 7.2 \mathrm{Ma})$, 古地中海成为一个巨大的内陆海, 并在持续的干旱环境下由盐沼蒸发为古地中海盐漠 $(6 \sim 5.3 \mathrm{Ma})^{[25 \sim 30]}$. 古地中海干涸和青藏高原的抬升可 

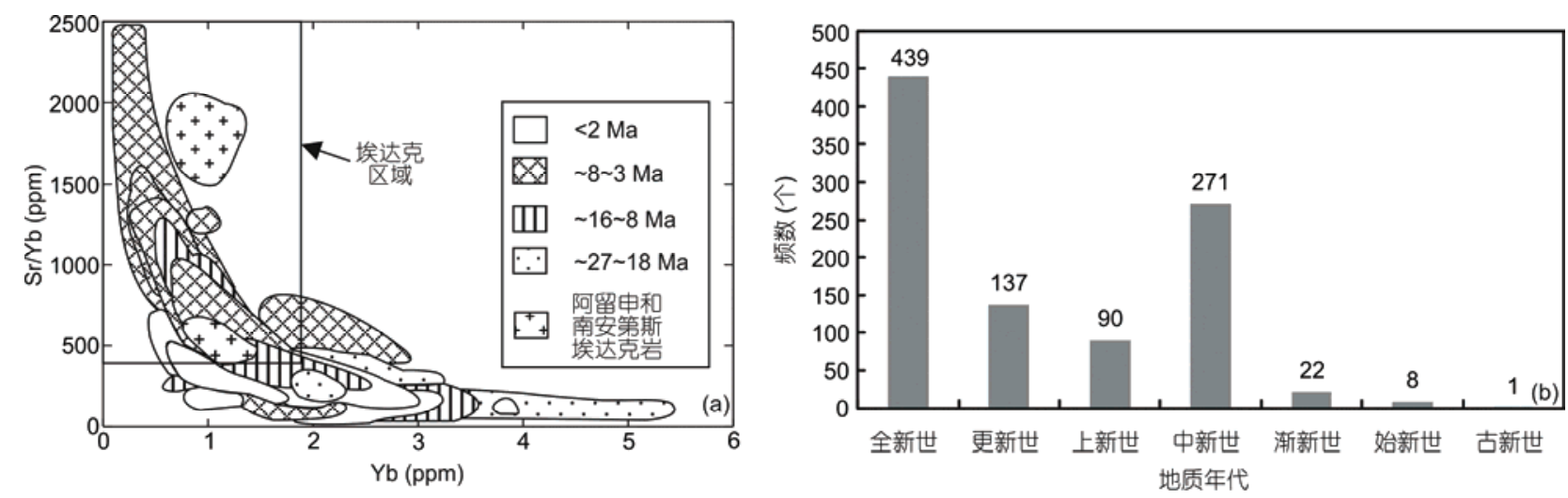

图 3 安第斯中酸性岩浆岩 $\mathrm{Yb}-\mathrm{Sr} / \mathrm{Yb}$ 图 ${ }^{[20]}$ (a) 和安第斯地区新生代埃达克岩时代分布直方图(b)

Figure $3 \mathrm{Yb}$ versus $\mathrm{Sr} / \mathrm{Yb}$ plot for Andean medium-acid magmas from Miocene to present ${ }^{[20]}$ (a) and age distribution histogram of Cenozoic adakites from Andean region (b)

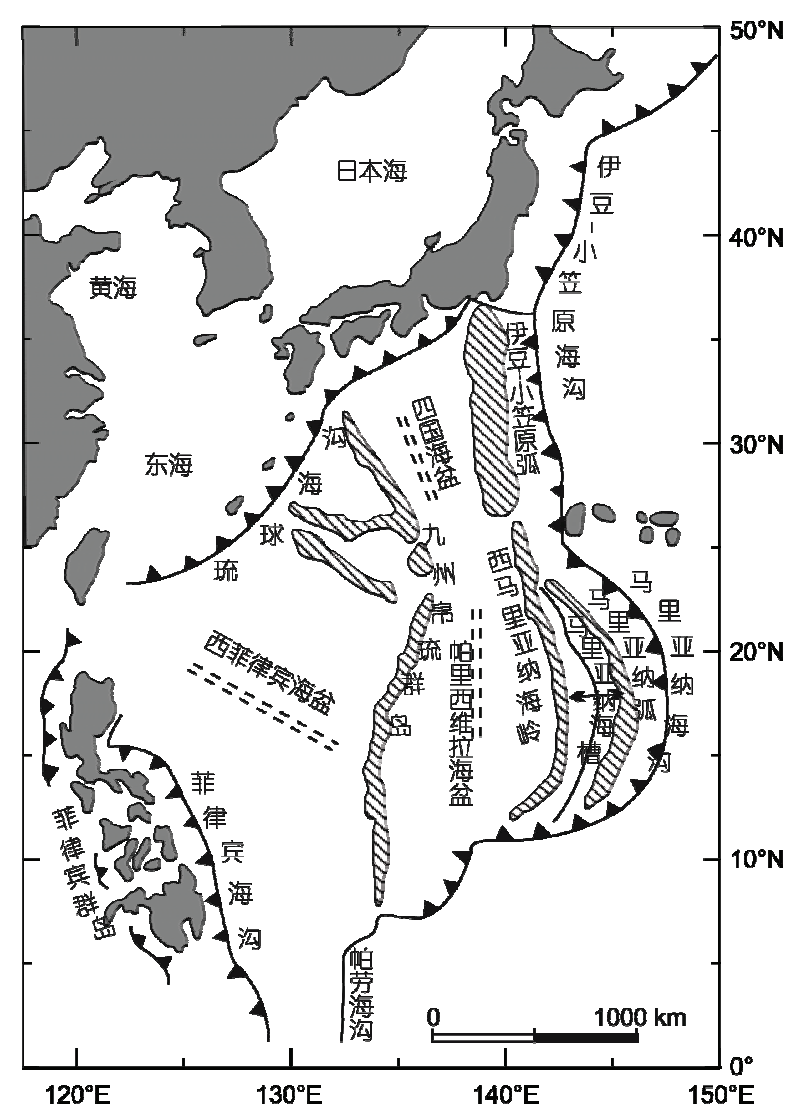

图 4 西太平洋边缘海盆构造格局 ${ }^{[3,23]}$

Figure 4 Tectonic distribution of the marginal sea basins in Western Pacific Ocean ${ }^{[3,23]}$

能共同造成了由非洲撒哈拉向东, 经过中东、中亚至 中国西部大片荒漠的形成 ${ }^{[23,29,31]}$ (图5).

\section{5 洋盆沉积加速事件}

新生代全球三大洋沉积速率在始新世较快, 此
后经历了长达 $25 \mathrm{Ma}$ 的低速期，从中新世开始又明显 增速, 并在中新世中期达到了峰值, 其速率为低速期

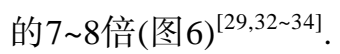

\section{6 人科动物的出现}

人类起源是科学界一个重大的未决问题，目前 生物学界认为, 早期人类起源于7 6 $\mathrm{Ma}$ 的晚中新世, 推测可能是晚中新世地球上发生了重大和恶劣的环 境突变事件(古地中海干涸和非洲中部大范围荒漠 化), 从而导致了非洲哺乳动物灵长目类人猿分化进 化出大猩猩与智人的祖先 ${ }^{[29,35,36]}$.

\section{3 讨论}

中新世全球发生了一系列重要的事件, 如：青藏 高原的抬升及黄土高原荒漠化、安第斯高原的抬升、 地中海的干涸、西太平洋海盆的发育等等. 上述事件 发生的原因是什么? 其间是否存在某种关联? 是一 个值得深人探讨的全球性课题. 本文初步认为中新 世各类事件可能直接或间接与板块活动加剧有关. 当板块扩张速度明显增加时，板块挤压导致地壳加 厚, 从而引起环境变化.

(1) 研究表明, 全球岩浆活动或在中新世开始活 跃, 或在中新世达到巅峰状态(图1和3)。中新世岩浆 活动变得强烈的原因是什么? 推测该时期岩浆事件 或许与板块加速运动有关. 如图7所示, 新生代以来, 太平洋板块扩张在中新世时期明显加速, 尤其是东 太平洋板块的东翼, 安第斯山在中新世的隆升可能 受这个因素的影响. 裂谷玄武岩和洋岛玄武岩也是 中新世发育, 上述岩浆大多来源于下地幔, 与地幔柱 


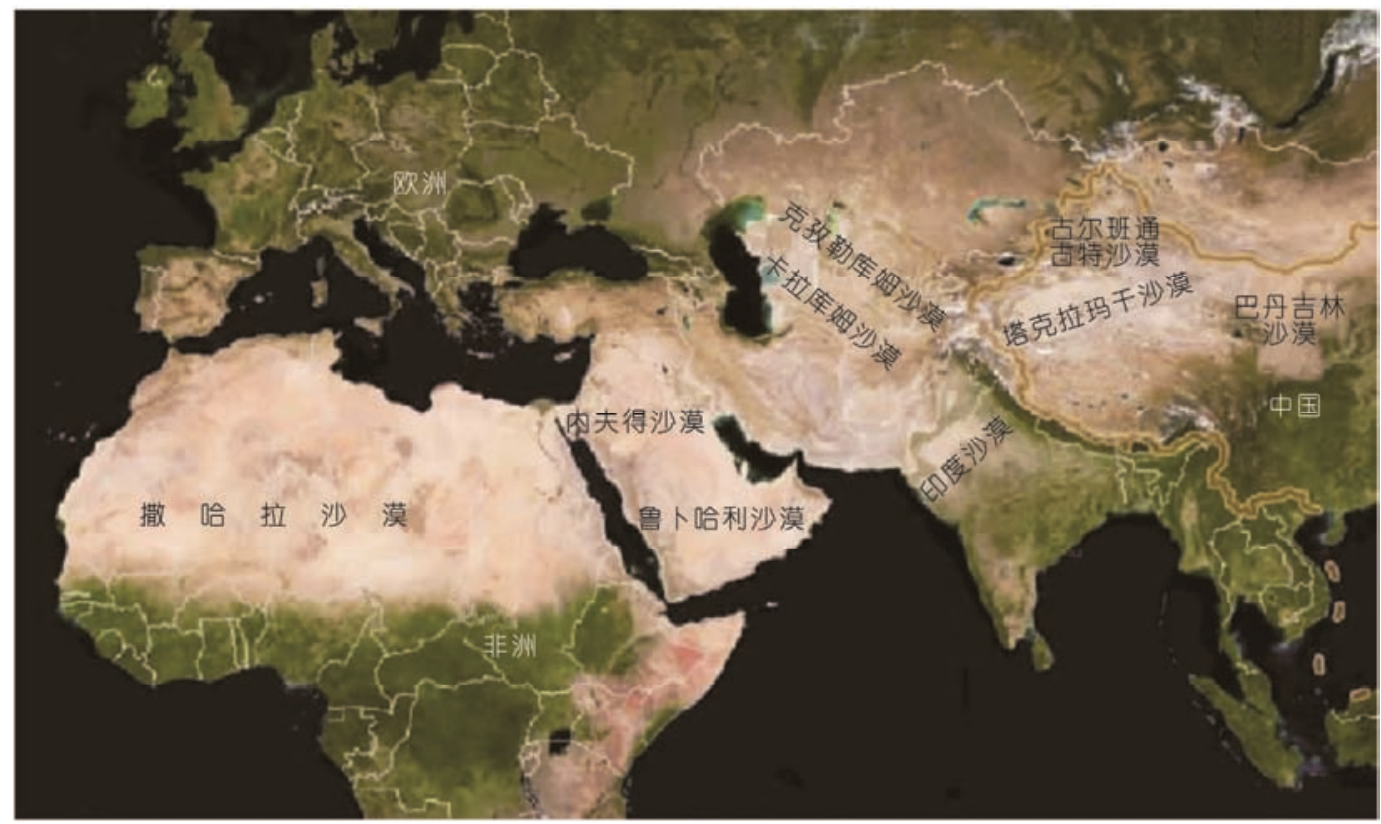

图 5 世界主要荒漠格局示意图 ${ }^{[29]}$

Figure 5 Sketch map showing the desert distribution in the World ${ }^{[29]}$

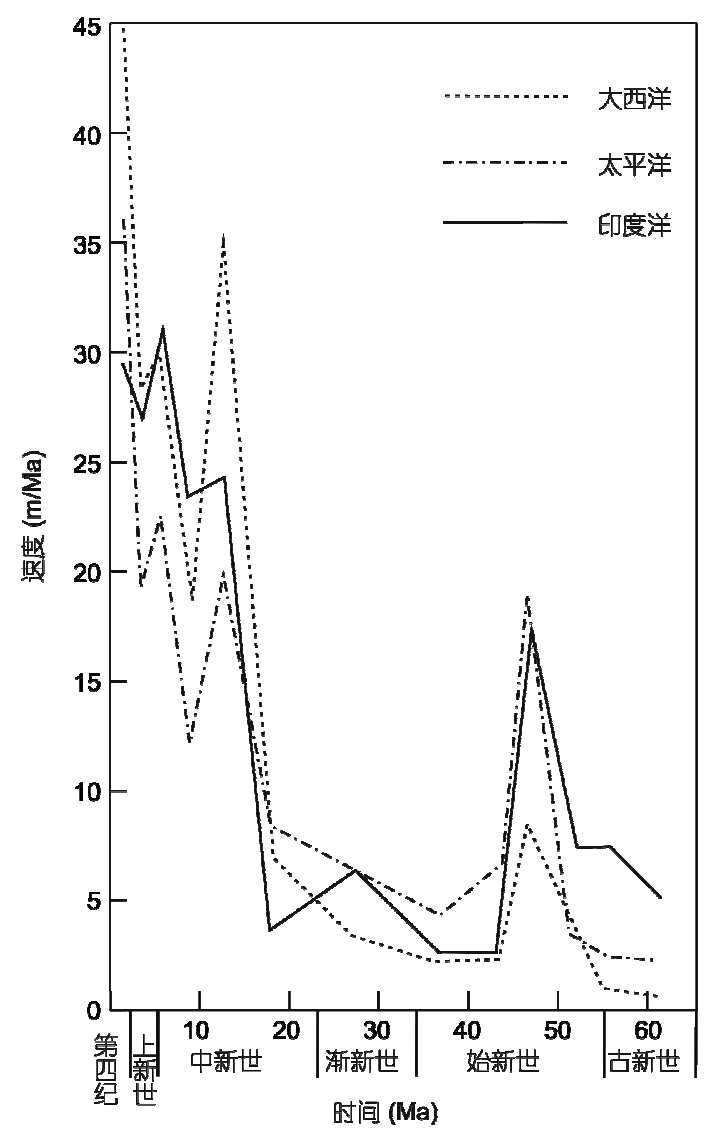

图 6 新生代大洋沉积物堆积速率 ${ }^{[28,30]}$

Figure 6 The accumulation rate of oceanic sediments in the Cenozoic ${ }^{[28,30]}$
的活动有关，暗示下地幔(核幔边界)在中新世也处于 活跃期, 原因何在值得研究.

（2）全球新生代高原以青藏高原和安第斯高原 最著名, 其实, 可能还有更多的高原, 只是已经垮塌 而不被人们所了解. 然而，根据埃达克岩的产出可以 追踪早先的高原. 统计表明, 新生代埃达克岩主要出 现在中新世(图8(a)), 因此表明，中新世可能是全球 高原最多的时期, 是全球地壳加厚的重要时期. 全球 新生代埃达克岩分布显示，可能的高原主要分布在 北美西部、土耳其-伊朗以及欧洲的喀尔巴阶等地(图 8(b)). 如阿拉伯和欧亚板块, 大约是在渐新世晚期开 始碰撞, 强烈碰撞可能发生在20 10 Ma, 碰撞导致 土耳其-伊朗高原的形成 ${ }^{[39]}$. 需要指出的是, 分布于 大洋的埃达克岩, 大多是 $\mathrm{O}$ 型的, 与板块俯冲有关; 分布于大陆的埃达克岩, 大多属于 $\mathrm{C}$ 型的, 是地壳加 厚的结果.

全球大洋沉积物在中新世加速堆积的原因通常 解释为与地中海干涸以及全球荒漠化作用有关, 荒 漠引发盐碱粉尘及黏土粉尘的增加, 沉降于深海盆 所致. 此外, 是否还可能与地壳加厚有关? 在青藏高 原, 中新世埃达克岩主要分布在喜马拉雅、冈底斯和 可可西里地区. 青藏高原地壳加厚可能是从始新世 ( 40 Ma)开始的(芫塘-金沙江地区)；中新世早期 


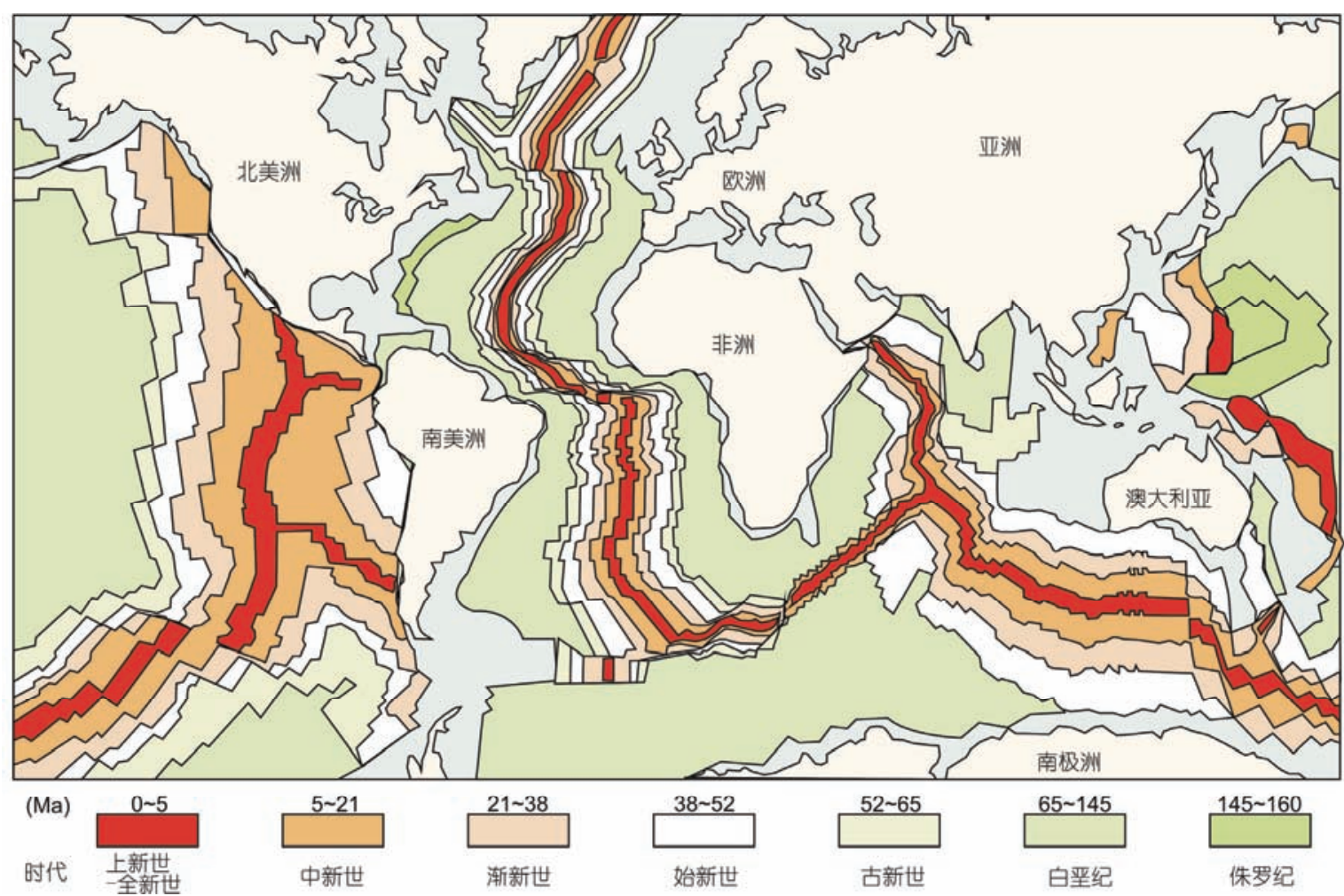

图 7 全球洋底时代分布示意图 ${ }^{[37,38]}$

Figure 7 Age distribution of global ocean floor ${ }^{[37,38]}$
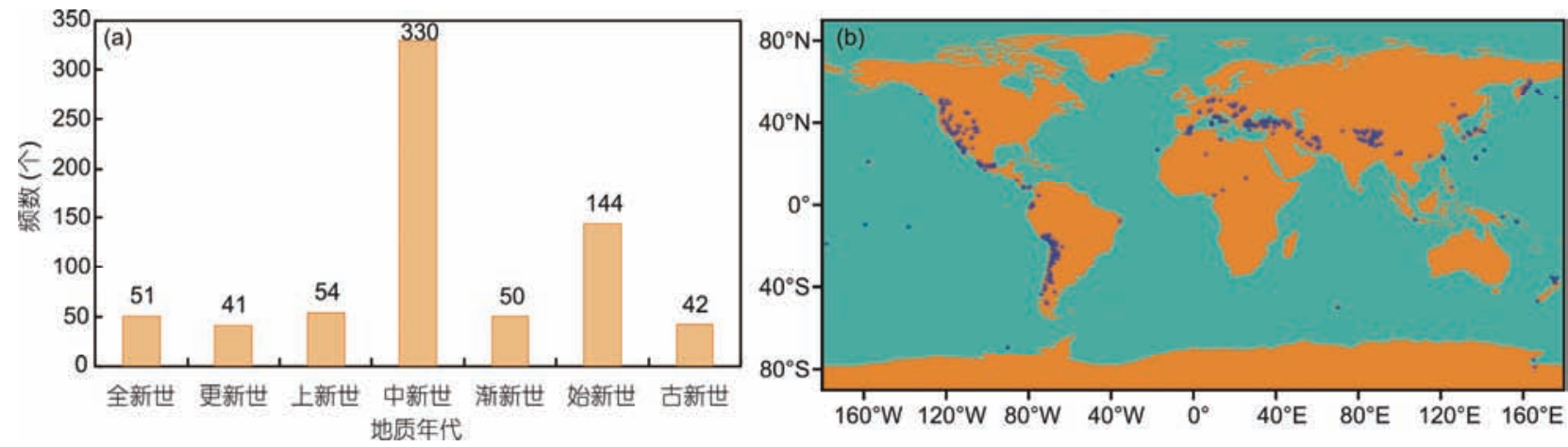

图 8 全球新生代埃达克岩时代分布直方图(a)和全球新生代埃达克岩分布图(b)

Figure 8 Age distribution histogram of global Cenozoic adakite (a) and global Cenozoic adakite distribution map (b)

( 23 20 Ma)由于主中央冲断层的活动, 高原整体抬 升; 至中新世中期( 17 Ma)高原全面抬升. 青藏高原 地壳在中新世中期强烈加厚, 地表抬升, 必将造成大 规模的侵蚀作用, 使得大量沉积物堆积于海盆边缘, 为大洋沉积物提供了丰富的物源, 而后随洋流带至 全球洋盆 ${ }^{[32]}$.

岩浆活动与构造运动总是相伴而生, 二者的相 互作用不断改变着古地理、古气候、古环境. 地壳加
厚源自构造的强烈挤压，导致地壳缩短，形成高原和 高山. 这些高原与高山的隆起影响了大气环流，从而 改变了地表环境.中国西部荒漠化以及黄土高原的 形成与青藏高原的崛起有关, 可能并非偶然. 地中海 的干涸事件发生于中新世晚期，可能也和喀尔巴阶 山和阿尔卑斯山的抬升有关.

（3）中新世事件的影响遍及大半个中国，包括中 国西部(大兴安岭-太行山-雪峰山一线以西)地壳加 
厚、红河的走滑、南海的张开、塔克拉玛干-内蒙古 沙漠的形成、黄土高原的形成等. 中国现今的气候、 环境的变化(不仅西部, 可能也包括中国南方) 也可追 溯至中新世时期. 因此, 研究中新世岩浆活动、构造 变动、地壳加厚与气候、环境之间的相互关系, 可能 是目前和长远一个需要花大力气研究的课题.

（4）中外科学家很早就注意到青藏高原抬升 与气候、环境变化及对人类活动影响的研

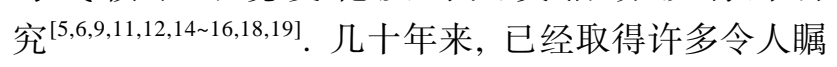
目的成果. 从目前看来, 上述事件主要发生在中新世 时期, 而且, 越来越多的事实说明, 岩浆-构造-气候环境之间可能存在某种联系. 因此, 加强地质、岩石、 构造与地理、气候、环境学科之间的沟通与合作是非 常必要的, 也许这样的联系可以推出一个全新的构 造-气候-环境理论, 这是中国科学家应当为之努力的 重要方向和目标.

(5) 大数据技术是当今社会的热门话题. 近年 来, 大数据已成功应用于互联网领域、物流领域、金 融领域, 大数据在监控系统、商业模式、犯罪预测等
方面甚至取得了令人惊叹的结果. 相比之下, 大数据 应用于科学研究领域还比较薄弱, 或者说还未真正 得到重视 ${ }^{[40]}$. 不强调“因果关系”, 重视“关联关系”; 不关注“为什么”, 只关心“是什么”; 不重视抽样, 而 重视全体, 是大数据思维的 3 个重要取向. 科学家研 究的对象是物质, 主要是通过逻辑推理探寻物质之 间的因果关系来认知世界的. 从探求因果关系转变 为探求关联关系, 对于科学家来说并非易事. 其实, 大数据的特点主要不在于数据量大, 而在于思想新, 用新思想去处理数据才是大数据的特点. 大数据并 不排斥因果关系, 而是从数据的因果关系出发, 探寻 数据间的关联关系, 发现数据的价值. 本文从全体数 据出发, 探讨数据之间的关联关系, 所得到的一些初 步成果应该是有意义的. 中新世全球发生了哪些事 件? 还有哪些是我们不知道的? 中新世诸多事件间 是否存在关联性? 其原因是什么? 又有何意义? 许 多问题我们仍还不清楚, 需要进一步去探索. 中国有 着研究中新世事件和记录的广阔天地, 我们还应继 续努力, 为全球地球科学做出我们应有的贡献. 勇研究员的关注; 郭正堂院士给我们以具体的指导, 提出了许多很好的意见和建议; 翟明国院士为我们组织了 一个小型的研讨会, 中国科学院地质与地球物理研究所孙继敏、孟庆任研究员、中国科学院广州地球化学研究 所徐义刚研究员及同济大学赵西西博士等对我们的研究提出了许多很好的意见, 我们受益匪浅; 西北大学数学 学院张海教授从数理统计方面为本文提供了许多帮助与建议. 研究期间还得到中国地质大学(北京)王璐同学以 及兰州大学陈万峰、杨婧、潘振杰、杜雪亮等同学的帮助, 特此表示衰心的感谢.

\section{参考文献}

1 Sarbas B, Nohl U. The GEOROC database-A decade of “online geochemistry”. Geochim Cosmochim Acta, 2009, 73: A1158

2 Rowley D B. Age of initiation of collision between India and Asia: A review of stratigraphic data. Earth Planet Sci Lett, 1996, 145: 1-13

3 Patriat P, Achache J. India-Eurasia collision chronology has implications for crustal shortening and driving mechanism of plates. J Polit Econ, 1984, 48: 183

4 Zhang Q, Wang Y L, Jin W J, et al. Criteria for the recognition of pre-, syn- and post-orogenic granitic rocks (in Chinese). Geol Bull China, 2008, 27: 1-18 [张旗, 王元龙, 金惟俊, 等. 造山前、造山和造山后花岗岩的识别. 地质通报, 2008, 27: 1-18]

5 Molnar P, Stock J M. Slowing of India's convergence with Eurasia since 20 Ma and its implications for Tibetan mantle dynamics. Tectonics, 2009, 28: TC3001, doi: 10.1029/2008TC002271

6 Molnar P. The growth of the Tibetan Plateau and Mio-Pliocene evolution of East Asian climate. Palaeontol Electron, 2005, 8: 131-142

7 Gilley L D, Harrison T M, Leloup P H, et al. Direct dating of left-lateral deformation along the Red River shear zone, China and Vietnam. J Geophys Res-Atmos, 2003, 108: 183-185

8 Harrison T M, Leloup P H, Ryerson F J, et al. Diachronous initiation of transtension along the Ailao Shan-Red River shear zone, Yunnan and Vietnam. World Region Geol, 1996, 1: 208-226

9 Tapponnier P, Peltzer G, Armijo R. On the mechanics of the collision between India and Asia. Geol Soc Lond Spec Publ, 1986, 19: 113-157

10 Wang E, Fan C, Wang G, et al. Deformational and geomorphic processes in the formation of the Ailao Shan-Diancang Range, west Yunnan (in Chinese). Quat Sci, 2006, 26: 220-227 [王二七, 㚞春, 王刚, 等. 滇西哀牢山-点苍山形成的构造和地貌过程. 第四纪研 究, 2006, 26: 220-227] 
11 Wang E. Evolution of the Tibetan Plateau: As constrained by major tectonic-thermo events and a discussion on their origin (in Chinese). Chin J Geol, 2013, 2: 334-353 [王二七. 青藏高原大地构造演化一一主要构造一热事件的制约及其成因探讨. 地质科学, 2013, 2: 334-353]

12 Wang E, Meng Q R. Mesozoic and Cenozoic tectonic evolution of the Longmenshan fault belt. Sci China Ser D-Earth Sci, 2009, 52: 579-592 [王二七, 孟庆任. 对龙门山中生代和新生代构造演化的讨论. 中国科学 D 辑: 地球科学, 2008, 38: 1221-1233]

13 Zhang Z S, Guo Z T. Spatial character reconstruction of different periods in Oligocene and Miocene (in Chinese). Quat Sci, 2005, 25: 523-530 [张仲石, 郭正堂. 根据地质记录恢复渐新世和中新世不同时期环境空间特征及其意义. 第四纪研究, 2005, 25: 523-530]

14 Liu D S, Zheng M P, Guo Z T. Initiation and evolution of the Asian monsoon system timely coupled with the ice-sheet growth and the tectonic movements in Asia (in Chinese). Quat Sci, 1998, 3: 194-204 [刘东生, 郑绵平, 郭正堂. 亚洲季风系统的起源和发展及其与 两极冰盖和区域构造运动的时代耦合性. 第四纪研究, 1998, 3: 194-204]

15 Lu H Y, Guo Z T. Evolution of the monsoon and dry climate in East Asia during late Cenozoic: A review. Sci China Earth Sci, 2014, 57: 70-79 [鹿化显, 郭正堂. 晚新生代东亚气候变化: 进展与问题. 中国科学：地球科学, 2013, 43: 1907-1918]

$16 \mathrm{Hu}$ F, Yang X. Geochemical and geomorphological evidence for the provenance of aeolian deposits in the Badain Jaran Desert, northwestern China. Quat Sci Rev, 2015, 131: 179-192

17 Xiao G Q, Zhang C X, Guo Z T. Initiation of East Asian monsoon system related to Tibetan Plateau uplift from the latest Oligocene to the earliest Miocene (in Chinese). Chin J Nat, 2014, 36: 165-169 [肖国桥, 张春霞, 郭正堂. 晚渐新世-早中新世青藏高原隆升与东亚 季风演化. 自然杂志, 2014, 36: 165-169]

18 An Z S, Zhang P Z, Wang E, et al. Changes of the monsoon-arid environment in China and growth of the Tibetan Plateau since the Miocene (in Chinese). Quat Sci, 2006, 26: 678-693 [安芷生, 张培震, 王二七，等. 中新世以来我国季风-干旱环境演化与青藏高原的生 长. 第四纪研究, 2006, 26: 678-693]

19 An Z S, Kutzbach J E, Prell W L, et al. Evolution of Asian monsoons and phased uplift of the Himalaya-Tibetan Plateau since Late Miocene times. Nature, 2001, 411: 62-66

20 Kay R W, Kay S M. Andean adakites: Three ways to make them. Acta Petrol Sin, 2002, 18: 303-311

21 Shi X F, Yan Q S. Magmatism of typical marginal basins (or back-arc basins) in the West Pacific (in Chinese). Adv Earth Sci, 2013, 28: 737-750 [石学法, 鄢全树. 西太平洋典型边缘海盆的岩浆活动. 地球科学进展, 2013, 28: 737-750]

22 Hall R. Cenozoic geological and plate tectonic evolution of SE Asia and the SW Pacific: Computer-based reconstructions, model and animations. J Asian Earth Sci, 2002, 20: 353-431

23 Jin X C. Ocean drilling program and tectonics of the Western Pacific region (in Chinese). Adv Earth Sci, 1995, 10: 234-239 [金性春. 大 洋钻探与西太平洋构造. 地球科学进展, 1995, 10: 234-239]

24 Несис К Н, Zhu F H, Shan L F. The Tethys dried up and its' consequences (in Chinese). Marine Geol Lett, 2001, 17: 15-17 [Hecuc K H, 朱佛宏, 单连芳. 地中海的干涸及其产生的后果. 海洋地质动态, 2001, 17: 15-17]

25 Boulton S J, Smart C W, Consolaro C, et al. The Miocene-Pliocene boundary and the Messinian Salinity Crisis in the easternmost Mediterranean: Insights from the Hatay Graben (Southern Turkey). Sediment Geol, 2015, 332: 51-67

26 Christeleit E C, Brandon M T, Zhuang G. Evidence for deep-water deposition of abyssal Mediterranean evaporites during the Messinian salinity crisis. Earth Planet Sci Lett, 2015, 427: 226-235

27 Hsü K J, Ryan W B F, Cita M B. Late Miocene desiccation of the Mediterranean. Nature, 1973, 242: 240-244

28 Hsü K J, Montadert L, Bernoulli D, et al. History of the Mediterranean salinity crisis. Nature, 1977, 267: 399-403

29 Song H L. Late Miocene environmental crises and their impacts: Desiccation of the Mediterranean and its bearing on world desertification and hominid appearance (in Chinese). Marine Geol Quat Geol, 2013, 33: 51-62 [宋怀龙. 晚中新世末期重大环境群发事件的影响 与评估——古地中海干涸与世界荒漠及人科动物的形成. 海洋地质与第四纪地质, 2013, 33: 51-62]

30 Lugli S, Manzi V, Roveri M, et al. The deep record of the Messinian salinity crisis: Evidence of a non-desiccated Mediterranean Sea. Paleogeogr Palaeoclimatol Palaeoecol, 2015, 433: 201-218

31 Sun J, Liu T. The age of the Taklimakan Desert. Science, 2006, 312: 1621

32 Davies T A, Hay W W, Southam J R, et al. Estimates of Cenozoic oceanic sedimentation rates. Science, 1977, 197: 53-55

33 Sun J, Zhang Z, Zhang L. New evidence on the age of the Taklimakan Desert. Geology, 2009, 37: 159-162

34 Xu Q Q. Prehistoric Climatology (in Chinese). Beijing: Science and Technology Publish, 1991 [徐钦琦. 史前气候学. 北京: 北京科学 技术出版社, 1991]

35 Vignaud P, Duringer P, Mackaye H T, et al. Geology and palaeontology of the Upper Miocene Toros-Menalla hominid locality, Chad. Nature, 2002, 418: 152-155

36 Brunet M. Palaeoanthropology (communication arising): Sahelanthropus or "Sahelpithecus"? Nature, 2002, 419: 581-582

37 Bouysse P. The Third Edition of the Geological Map of the World. Episodes, 2010, 33: 173-182

38 Ren J S, Xu Q Q, Zhao L, et al. Looking for submerged landmasses (in Chinese). Geol Rev, 2015, 61: $969-989$ [任纪舜，徐芹芹，赵否， 等. 寻找消失的大陆. 地质论评, 2015, 61: 969-989]

39 Faccenna C, Bellier O, Martinod J. Slab detachment beneath eastern Anatolia: A possible cause for the formation of the North Anatolian fault. Earth Planet Sci Lett, 2006, 242: 85-97

40 Guo H D, Wang L Z, Chen F, et al. Scentific big data and digital Earth (in Chinese). Chin Sci Bull, 2014, 59: 1047-1054 [郭华东, 王力 哲, 陈方, 等. 科学大数据与数字地球. 科学通报, 2014, 59: 1047-1054] 


\title{
Global major events in Miocene and its significance: Revela- tion from data mining
}

\author{
LIU XinYu ${ }^{1}$, ZHANG Qi $^{2 *}$, ZHANG ChengLi $^{1 *}$, YUAN FangLin $^{1} \&$ JIAO ShouTao $^{3}$ \\ ${ }^{1}$ State Key Laboratory of Continental Dynamics, Department of Geology, Northwest University, Xi'an 710069, China; \\ ${ }^{2}$ Institute of Geology and Geophysics, Chinese Academy of Sciences, Beijing 100029, China; \\ ${ }^{3}$ School of Earth Science and Geological Engineering, Sun Yat-sen University, Guangzhou 510275, China \\ * Corresponding authors, E-mail: zq1937@126.com; clzhang@nwu.edu.cn
}

The GEOROC (Geochemistry of Rocks of the Ocean-sand Continents) database is a comprehensive global petrological database and it is constantly updated and available online to users around the world. Based on this database, we analyze the age data of the global Cenozoic igneous rocks including convergent margin andesite and basalt, continental rift andesite and basalt, ocean island andesite and basalt, adakite, and so on. Statistical analysis reveals that the global magmatism either became active in the Miocene or peaked in the Miocene. Magmatic rocks formed in different tectonic settings represent different geological effects: convergent margin magmatic rock suggests the speed up of subduction; the huge eruption of rift andesite and basalt indicates the occurrence of plate extension; the sharp increase of ocean island andesite and basalt indicates an abnormally active lower mantle, which brings materials from the lower mantle into the crust; a large scale of medium-acid magmatic rock represents the lower crust at high temperature and the asthenosphere mantle strongly upwelling, which leads to the crust intensely reforming; adakite is usually related to strongly tectonic pressing and results in crustal thickening in these areas. In addition, there was a series of significant events in the Miocene. For instance, the Tibetan Plateau rapidly uplifted in the middle Miocene, leading to the formation of the Loess Plateau; the Andean Mountains rose abruptly probably during 8-3 Ma; Tethys dried up from 20-5 Ma, which may have been a cause of the global desertification; the development of the western Pacific marginal sea basins mainly occurred during the late Oligocene to early Miocene.

We tried to explain the connection among all of these events as follows. Generally, magmatism usually goes with tectonic activities, and their interaction may change the paleogeography, paleoclimate, and paleoenvironment. The accelerated motion of the Pacific Plate in the Miocene could have thickened or raised the crust, resulting in the formation of the Andean mountains. The interaction between the Indian plate and Eurasian plate in the Miocene induced the speedy uplifting of the Tibetan Plateau. The new mountain and plateau reformed the original landscape and landform, which made these areas easily suffer weathering and erosion, and the resulting sediments were taken into global ocean basalts with ocean currents. As a result, the accumulation rate of oceanic sediments would have risen quickly. Furthermore, the upraising of the Andean and Tibetan Plateaus also influenced the general atmospheric circulation, which ultimately changed the environment; this might be an important reason why primitive man originated from the Miocene. In addition, as for China, the strike-slip fault in the Red River, the expansion of the South China Sea, and the formation of the Taklimakan Desert may be more or less related to the magmatism in the Miocene. There remain a number of problems to explore. Therefore, studying the interrelationship among magmatism, tectonic activity, climate, and environment in the Miocene should be a priority for geoscience workers in the present and future. Besides, scientific research is gradually entering the big data era, and geological science is no exception. The primary characteristic of big data research is not how big the data is but how creative the thought is. In this study, we took advantage of all available data to investigate the relationship among the data sets. The findings reveal that data mining with a global database can provide new insights and new lines of inquiry for scientific research in the future.

\section{Miocene, events, magmatic activity, data mining}

doi: 10.1360/N972016-00726 